Published in final edited form as:

Neurobiol Aging. 2013 December ; 34(12): 2889.e11-2889.e13. doi:10.1016/j.neurobiolaging. 2013.06.004.

\title{
Assessment of TREM2 R47H association with Alzheimer's disease in a population-based sample: The Cache County Study
}

\author{
Josue Gonzalez ${ }^{1,}$, , Cameron Schmutz $1{ }^{1,}$, Caitlin Munger ${ }^{1}$, Ammon Perkes ${ }^{1}$, Aaron Gustin ${ }^{1}$, \\ Michael Peterson ${ }^{1}$, Mark T. W. Ebbert ${ }^{1,2}$, Maria C. Norton ${ }^{3,4}$, JoAnn T. Tschanz $^{4}$, Ronald G. \\ Munger $^{5}$, Christopher D. Corcoran ${ }^{6}$, and John S. K. Kauwe ${ }^{1}$ \\ ${ }^{1}$ Department of Biology, Brigham Young University, E Campus Dr, Provo, Utah, USA 84602 \\ ${ }^{2}$ ARUP Institute for Clinical and Experimental Pathology, 500 Chipeta Way Salt Lake City, Utah, \\ USA \\ ${ }^{3}$ Department of Family Consumer and Human Development, Utah State University, 1400 Old \\ Main Hill Logan, Utah, USA 84322 \\ ${ }^{4}$ Department of Psychology, Utah State University, 1400 Old Main Hill Logan, Utah, USA 84322 \\ ${ }^{5}$ Department of Nutrition, Dietetics, and Food Sciences, Utah State University,1400 Old Main Hill \\ Logan, Utah, USA 84322 \\ ${ }^{6}$ Department of Mathematics and Statistics, Utah State University, 1400 Old Main Hill Logan, \\ Utah, USA 84322
}

\begin{abstract}
Recent studies have identified the R47H variant in TREM2 as an Alzheimer's disease (AD) risk factor with estimated odds ratio ranging from 2.9-5.1. The Cache County Memory Study is a large, population-based sample designed for the study of memory and aging. We genotyped rs 75932628 (R47H) in 2974 samples (427 cases and 2540 controls) from the Cache County study using a custom Taqman Assay. We observed 7 heterozygous cases and 12 heterozygous controls with an odds ratio of 3.5 (95\% confidence interval, $1.3-8.8 ; \mathrm{p}=0.0076)$. The minor allele frequency and population attributable fraction for $\mathrm{R} 47 \mathrm{H}$ were 0.0029 and 0.004 , respectively. This study replicates the association between $\mathrm{R} 47 \mathrm{H}$ and $\mathrm{AD}$ risk in a large, population-based sample and estimates the population frequency and attributable risk of this rare variant.
\end{abstract}

\section{Keywords}

Alzheimer's disease; human; TREM2; rare variant; R47H

\footnotetext{
(C) 2013 Elsevier Inc. All rights reserved.

*These authors contributed equally to this manuscript
}

Disclosure Statement

No authors report conflicts of interest, financial or otherwise.

Publisher's Disclaimer: This is a PDF file of an unedited manuscript that has been accepted for publication. As a service to our customers we are providing this early version of the manuscript. The manuscript will undergo copyediting, typesetting, and review of the resulting proof before it is published in its final citable form. Please note that during the production process errors may be discovered which could affect the content, and all legal disclaimers that apply to the journal pertain. 


\section{Introduction}

Alzheimer's disease (AD) is a fatal neurodegenerative disorder and is the leading cause of dementia in the elderly (Jonsson, et al., 2013). It is the sixth leading cause of death in the United States, and of the six, the only one lacking adequate treatment or prevention. AD is characterized by a progressive loss in cognitive function, and strikes memory early in the course. Neuropathological changes include loss of neurons and synapses, extensive accumulation of amyloid plaques, and neurofibrillary tangles. AD has been identified as a proteopathic disease due to its extensive accumulation of amyloid plaques and neurofibrillary tangles (Guerreiro, et al., 2013, Jonsson, et al., 2013).

Recent research has focused on finding rare genetic variants that increase risk for AD. Specifically, a rare variant known as $\mathrm{R} 47 \mathrm{H}$ in exon 2 of the TREM2 gene has been identified as a risk factor with odds ratio estimates between 2.9 and 5.1 (Guerreiro, et al., 2013, Jonsson, et al., 2013). Here we have assessed the R47H variant in a true populationbased sample to estimate the relative risk and population attributable fraction of this variant.

\section{Methods}

\subsection{Subjects}

The Cache County Study on Memory Health and Aging is a large population-based study initiated in 1994. The 5092 subjects represented approximately $90 \%$ of all residents in Cache County, Utah aged 65 years or older. For the present study, DNA samples were available for 2974 subjects. A more detailed summation of the Cache County Study has been reported previously (Breitner, et al., 1999). Briefly, case-control status was determined through a series of cognitive tests and dementia evaluations that were administered triennially for four examination waves. In the first stage of screening, cognitive function was measured by the Modified Mini-Mental State Exam-Revised (3MS-R). Individuals who were screened as positive cases and also a randomly selected subset (19\%) of individuals were invited to participate in subsequent stages of evaluation. These consisted of an informant interview and a clinical assessment, reviewed by a geropsychiatrist and neuropsychologist. At this time a preliminary diagnosis was assigned as dementia or another cognitive disorder. Those who were diagnosed with dementia were invited to participate in standard laboratory tests for dementia, an MRI scan, and a geropsychiatrist examination. At the conclusion of these tests, the final cognitive status of participants was determined by an expert panel consisting of neuropsychologists, geropsychiatrists, a neurologist and a cognitive neuroscientist. By consensus, diagnoses of AD were assigned by NINCDSADRDA criteria (McKhann, et al., 1984) and included probable AD cases. Cases for this study were those diagnosed with $\mathrm{AD}$ only and no comorbid types of dementia. The controls were identified as those individuals who had negative test results in all examinations and who showed no signs of dementia.

\subsection{Genotyping}

We performed SNP Genotyping for 2974 DNA samples from participants in the Cache County Study for rs75932628 (R47H) using a custom Taqman Assay. Included in the 2974 samples were 427 clinically ascertained prevalent and incident Alzheimer's disease cases and 2540 cognitively normal participants.

\subsection{Analysis}

Association between $\mathrm{R} 47 \mathrm{H}$ and case control status was tested using logistic regression models with adjustment for age, gender and $A P O E \in 4$ genotype. We calculated population attributable fractions using equation 1 (Ebbert, et al., 2013, International Parkinson Disease 
Genomics, et al., 2011, Naj, et al., 2011), where $p$ equals the allele frequency and OR represents the odds ratio.

$$
P A F=\frac{p(O R-1)}{p(O R-1)+1} \quad \text { EQUATION } 1
$$

\section{Results}

Our results replicated the significant association between R47H and AD. Of our 2974 samples we observed 7 heterozygous cases and 12 heterozygous controls with a Odds Ratio of 3.5 (95\% confidence interval, $1.3-8.8 ; \mathrm{p}=7.6 \mathrm{E}-03)$. The minor allele frequency and population attributable fraction for $\mathrm{R} 47 \mathrm{H}$ were 0.0029 and 0.004 , respectively.

\section{Discussion}

Recent studies (Guerreiro, et al., 2013, Jonsson, et al., 2013) identified an R47H variant in TREM2 as a risk factor for late-onset Alzheimer's disease. Several studies have replicated this work using different ethnic cohorts, study designs and sample sizes. One study (Pottier, et al., 2013) examined the association between the R47H variant and early-onset $\mathrm{AD}$ in Caucasian subjects of French origin, consisting of $726 \mathrm{AD}$ cases and 783 controls. The study concluded that the variant increases risk for $\mathrm{AD}$ with onset earlier than 65 years (OR, 4.07 and $\mathrm{p}=0.009$ ). Another study (Benitez, et al., 2013) researched a Spanish population and directly genotyped the $\mathrm{R} 47 \mathrm{H}$ variant in $504 \mathrm{AD}$ cases and 550 controls. $\mathrm{R} 47 \mathrm{H}$ was found in $1.4 \%(7 / 504)$ of $\mathrm{AD}$ cases and in $0 \%(0 / 550)$ of controls $(\mathrm{p}<0.009)$. A familial study (Giraldo, et al., 2013) tested a consanguineous Colombian family, that included 3 cases and 5 controls, reporting a missense mutation in exon 4 of TREM 2 causing frontotemporal dementia. They also found the $\mathrm{R} 47 \mathrm{H}$ variant to increase risk for late and early onset $\mathrm{AD}$ in $185 \mathrm{AD}$ cases and 183 controls (OR, 3.3). Despite the differences in demographics and size, each study concludes that the rs 75932638 variant increases AD risk.

Our work further supports the R47H variant increases risk for late-onset AD. Unlike previous studies, however, the Odds Ratio and Population Attributable fractions estimated here are from a large population-based sample. As such, they better estimate the effects of this allele in the general population. The estimated Odds Ratio of 3.5 in our study suggests that the increased $\mathrm{AD}$ risk for $\mathrm{R} 47 \mathrm{H}$ is comparable to the $A P O E \in 4$ allele. However, due to the low frequency of this variant in the general population, the population attributable fraction of the $\mathrm{R} 47 \mathrm{H}$ variant is very low (0.004 vs. 0.20 for the $A P O E \in 4$ allele in this sample). Therefore, the population effects are much lower than those of the APOE $\epsilon 4$ allele, lessening the potential clinical and diagnostic impact of this discovery. In conclusion, while the population-level effects of the R47H variant do not approach those of the APOE $\epsilon 4$ allele, TREM 2 has a clear and replicable effect on AD risk. The loss-of-function caused by the $\mathrm{R} 47 \mathrm{H}$ variant contributes to the disruption of an immune response that triggers an inflammatory response leading to neuronal cell death and may contribute to the degeneration of phagocytic pathways that aid in the clearance of neuronal cell debris (Neumann and Daly, 2013). These functions clearly play a role in $\mathrm{AD}$ and future preventative and therapeutic efforts can leverage this important new information.

\section{Acknowledgments}

This work was supported by grants from NIH (R01AG11380, R01AG21136, R01AG31272, R01AG042611), the Alzheimer's Association (MNIRG-11-205368), the Charleston Conference on Alzheimer's Disease and the Brigham Young University Gerontology Program. The authors thank the participants and staff of the Dementia Progression Study, the Utah Population Database, and the Cache County Study on Memory Health and Aging for 
their important contributions to this work. The funders had no role in study design, data collection and analysis, decision to publish, or preparation of the manuscript.

\section{References}

Benitez BA, Cooper B, Pastor P, Jin SC, Lorenzo E, Cervantes S, Cruchaga C. TREM2 is associated with the risk of Alzheimer's disease in Spanish population. Neurobiol Aging. 2013; 34(6):1711, e15-7.10.1016/j.neurobiolaging.2012.12.018 [PubMed: 23391427]

Breitner JC, Wyse BW, Anthony JC, Welsh-Bohmer KA, Steffens DC, Norton MC, Tschanz JT, Plassman BL, Meyer MR, Skoog I, Khachaturian A. APOE-epsilon4 count predicts age when prevalence of AD increases, then declines: the Cache County Study. Neurology. 1999; 53(2):32131. [PubMed: 10430421]

Ebbert M, Ridge PG, Wilson A, Sharp A, Bailey M, Norton M, Tschanz J, Munger R, Corcoran C, Kauwe JS. Population-based analysis of Alzheimer's disease risk alleles implicates genetic interactions. Biol Psychiatry. 2013 Submitted.

Giraldo M, Lopera F, Siniard AL, Corneveaux JJ, Schrauwen I, Carvajal J, Munoz C, RamirezRestrepo M, Gaiteri C, Myers AJ, Caselli RJ, Kosik KS, Reiman EM, Huentelman MJ. Variants in triggering receptor expressed on myeloid cells 2 are associated with both behavioral variant frontotemporal lobar degeneration and Alzheimer's disease. Neurobiol Aging. 2013; 34(8):2077, e11-8.10.1016/j.neurobiolaging.2013.02.016 [PubMed: 23582655]

Guerreiro R, Wojtas A, Bras J, Carrasquillo M, Rogaeva E, Majounie E, Cruchaga C, Sassi C, Kauwe JS, Younkin S, Hazrati L, Collinge J, Pocock J, Lashley T, Williams J, Lambert JC, Amouyel P, Goate A, Rademakers R, Morgan K, Powell J, St George-Hyslop P, Singleton A, Hardy J. Alzheimer Genetic Analysis G. TREM2 variants in Alzheimer's disease. N Engl J Med. 2013; 368(2):117-27.10.1056/NEJMoa1211851 [PubMed: 23150934]

Nalls MA, Plagnol V, Hernandez DG, Sharma M, Sheerin UM, Saad M, Simon-Sanchez J, Schulte C, Lesage S, Sveinbjornsdottir S, Stefansson K, Martinez M, Hardy J, Heutink P, Brice A, Gasser T, Singleton AB, Wood NW. International Parkinson Disease Genomics, C. Imputation of sequence variants for identification of genetic risks for Parkinson's disease: a meta-analysis of genome-wide association studies. Lancet. 2011; 377(9766):641-9.10.1016/S0140-6736(10)62345-8 [PubMed: 21292315]

Jonsson T, Stefansson H, Steinberg S, Jonsdottir I, Jonsson PV, Snaedal J, Bjornsson S, Huttenlocher J, Levey AI, Lah JJ, Rujescu D, Hampel H, Giegling I, Andreassen OA, Engedal K, Ulstein I, Djurovic S, Ibrahim-Verbaas C, Hofman A, Ikram MA, van Duijn CM, Thorsteinsdottir U, Kong A, Stefansson K. Variant of TREM2 associated with the risk of Alzheimer's disease. N Engl J Med. 2013; 368(2):107-16.10.1056/NEJMoa1211103 [PubMed: 23150908]

McKhann G, Drachman D, Folstein M, Katzman R, Price D, Stadlan EM. Clinical diagnosis of Alzheimer's disease: report of the NINCDS-ADRDA Work Group under the auspices of Department of Health and Human Services Task Force on Alzheimer's Disease. Neurology. 1984; 34(7):939-44. [PubMed: 6610841]

Naj AC, Jun G, Beecham GW, Wang LS, Vardarajan BN, Buros J, Gallins PJ, Buxbaum JD, Jarvik GP, Crane PK, Larson EB, Bird TD, Boeve BF, Graff-Radford NR, De Jager PL, Evans D, Schneider JA, Carrasquillo MM, Ertekin-Taner N, Younkin SG, Cruchaga C, Kauwe JSK, Nowotny P, Kramer P, Hardy J, Huentelman MJ, Myers AJ, Barmada MM, Demirci FY, Baldwin CT, Green RC, Rogaeva E, St George-Hyslop P, Arnold SE, Barber R, Beach T, Bigio EH, Bowen JD, Boxer A, Burke JR, Cairns NJ, Carlson CS, Carney RM, Carroll SL, Chui HC, Clark DG, Corneveaux J, Cotman CW, Cummings JL, DeCarli C, DeKosky ST, Diaz-Arrastia R, Dick M, Dickson DW, Ellis WG, Faber KM, Fallon KB, Farlow MR, Ferris S, Frosch MP, Galasko DR, Ganguli M, Gearing M, Geschwind DH, Ghetti B, Gilbert JR, Gilman S, Giordani B, Glass JD, Growdon JH, Hamilton RL, Harrell LE, Head E, Honig LS, Hulette CM, Hyman BT, Jicha GA, Jin LW, Johnson N, Karlawish J, Karydas A, Kaye JA, Kim R, Koo EH, Kowall NW, Lah JJ, Levey AI, Lieberman AP, Lopez OL, Mack WJ, Marson DC, Martiniuk F, Mash DC, Masliah E, McCormick WC, McCurry SM, McDavid AN, Mckee AC, Mesulam M, Miller BL, Miller CA, Miller JW, Parisi JE, Perl DP, Peskind E, Petersen RC, Poon WW, Quinn JF, Rajbhandary RA, Raskind M, Reisberg B, Ringman JM, Roberson ED, Rosenberg RN, Sano M, Schneider LS, Seeley W, Shelanski ML, Slifer MA, Smith CD, Sonnen JA, Spina S, Stern RA, Tanzi RE, Trojanowski JQ, Troncoso JC, Van Deerlin 
VM, Vinters HV, Vonsattel JP, Weintraub S, Welsh-Bohmer KA, Williamson J, Woltjer RL, Cantwell LB, Dombroski BA, Beekly D, Lunetta KL, Martin ER, Kamboh MI, Saykin AJ, Reiman EM, Bennett DA, Morris JC, Montine TJ, Goate AM, Blacker D, Tsuang DW, Hakonarson H, Kukull WA, Foroud TM, Haines JL, Mayeux R, Pericak-Vance MA, Farrer LA, Schellenberg GD. Common variants at MS4A4/MS4A6E, CD2AP, CD33 and EPHA1 are associated with late-onset Alzheimer's disease. Nat Genet. 2011; 43(5):436-+. [PubMed: 21460841]

Neumann H, Daly MJ. Variant TREM2 as risk factor for Alzheimer's disease. N Engl J Med. 2013; 368(2):182-4.10.1056/NEJMe1213157 [PubMed: 23151315]

Pottier C, Wallon D, Rousseau S, Rovelet-Lecrux A, Richard AC, Rollin-Sillaire A, Frebourg T, Campion D, Hannequin D. TREM2 R47H variant as a risk factor for early-onset Alzheimer's disease. Journal of Alzheimer's disease : JAD. 2013; 35(1):45-9.10.3233/JAD-122311 